\title{
EFISIENSI PEMBIAYAAN BANK PEMBIAYAAN RAKYAT SYARIAH (BPRS) DI JAWA TIMUR PERIODE 2014-2017. ANALISIS DENGAN METODE DEA (CRS,VRS, dan Skala)
}

\author{
Aziza Hanifa Khairunnisa ${ }^{1 *}$ and Nisful Laila ${ }^{2}$ \\ 1,2 Universitas Airlangga, Surabaya, Indonesia
}

\begin{abstract}
This research aimed to find out the efficiency level of financing of Islamic Rural Bak in East Java. Input variables used were the rights of third party on profit sharing and PPAP cost, while output variable used was main operational income. Method used to measure efficiency level was Data Envelopment Analysis (DEA) with the assumption of Variable Return to Scale and the input and output orientations. The measurement of efficiency value with VRS assumption resulted three efficiency values, which are Technical Efficiency (VRS), Economic Efficiency (CRS), and Scale Efficiency. Then, these three values were analyzed further to get to know the source of inefficiency of financing in inefficient Islamic Rural Bank.
\end{abstract}

Keywords: BPRS, Data Envelopment Analysis (DEA)Efficiency, Financing

\section{PENDAHULUAN}

Bank Pembiayaan Rakyat Syariah merupakan bagian dari sistem perbankan syariah. Keberadaan BPRS didasari oleh undang-undang yang telah dibuat mengenai perbankan syariah. Keberadaan BPRS secara khusus dijabarkan dalam bentuk Surat Keputusan Direksi Bank Indonesia No. 32/36/Kep/Dir, tertanggal 12 Mei 1999 dan Surat Edaran Bank Indonesia No. 32/4/KPPB tanggal 12 Mei 1999 tentang Bank Perkreditan Rakyat berdasarkan Prinsip Syariah

Keberadaan BPRS dimaksudkan untuk dapat memberikan layanan perbankan secara cepat, mudah dan sederhana kepada masyarakat khususnya pengusaha menengah, kecil dan mikro baik di perdesaan maupun perkotaan. Tujuan didirikannya BPRS adala huntuk memfasilitasi masyarakat yang tidak memiliki akses ke bank umum untuk memperoleh pembiayaan serta didasari oleh prinsip tolong menolong dalam kebaikan, sebagai mana dinyatakan dalam surat Al-Maidah ayat 2.

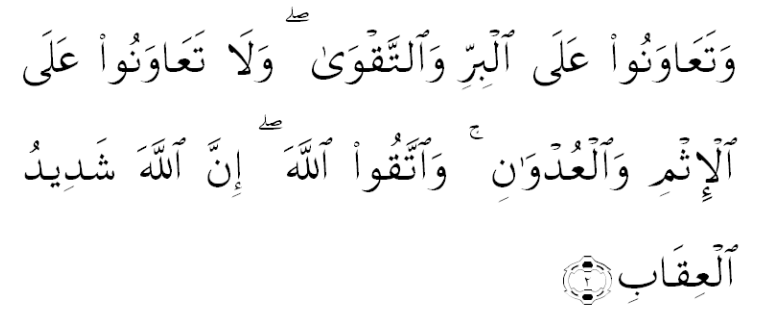

“...wata' āwanū 'ala al-birriwa at-taqwā, walāta'āwanū 'ala al-itsmiwaal udwāni. Wattaqullaha, innallahasyadidul 'iqobi."

* Corresponding author. Email address: aziza.hanifa.khairun-2014@feb.unair.ac.id 
“...dan tolong-menolonglah kamu dalam (mengerjakan) kebajikan dan takwa, dan jangan tolong-menolong dalam berbuat dosa dan pelanggaran. Dan bertakwalah kamu kepada Allah, Sesungguhnya Allah Amat berat siksa-Nya." (Departemen Agama, 2005 : 142).

Analisis mengenai efisiensi menjadi sangat penting karena penghimpunan dan penyaluran pembiayaan yang ekspansif tanpa memperhatikan faktor efisiensi akan berpengaruh terhadap profitabilitas bank yang bersangkutan. Efisiensi merupakan salah satu tolak ukur yang dapat dilihat untuk mengukur kinerja suatu BPRS. (Muharam dan Purvitasari, 2007:15).

Efisiensi secara umum menurut Martic et.al (2009:37), adalah kemampuan suatu unit bisnis untuk mencapai target bisnis dengan menggunakan seminimal mungkin sumber daya yang ada. Konsep efisiensi merupakan salah satu prinsip yang sangat penting dalam bisnis. Dari sudut pandang ekonomi islam, setiap muslim dalam menjalankan bisnisnya haruslah memiliki keinginan yang kuat untuk meningkatkan efisiensi, yaitu dengan mengurangi biaya demi kebaikan konsumennya (Affandi (2002) dalam Kamaruddin, et. al 2008:33).

Metode pengukuran efisiensi dapat dikelompokkan atas dua kategori utama yaitu metode parametrik dan non-parametrik. Metode yang umum digunakan adalah Data Envelopment Analysis (DEA) karena merupakan metode yang banyak digunakan dan paling fleksibel untuk digunakan. Cooper,et.al (2011: 2)

Dalam perhitungannya dapat dilakukan dengan 2 asumsi, yaitu asumsi Constan Return to Scale (CSR) dan Variable Return to Scale (VRS). Model Constan Return to Scale adalah model yang mengasumsikan bahwa BPRS telah beroperasi pada skala optimalnya. Sehingga, pengukuran tingkat efisiensi teknis yang dihasilkan merupakan Overall Technical efficiency (OTE) yaitu, nilai efisensi yang berkaitan dengan kemampuan manajerial bank dalam mengelola input untuk menjadi output dan juga tingkat ukuran pembiayaannya.

Sedangkan model Variable to Scale adalah model yang mengasumsikan bahwa seluruh bank belum beroperasi pada skala optimalnya. Sehingga pengukuran dengan asumsi VRS ini bertujuan untuk mengukur tingkat efisiensi teknis manajerial pembiayaan murni (Pure Technical Efficiency) tanpa terbaurkan oleh skala ukuran pembiayaan bank.

Perbedaan atau gap pada nilai Overall Technical Efficiency dan Pure Technical Efficiency menggambarkan tingkat efisiensi skala pembiayaan (Scale Efficiency) suatu bank yang ditunjukkan dengan rasio Overall Technical Efficiency (OTE) terhadap Pure Technical Efficiency (PTE) . Oleh karena itu pengukuran efisiensi skala pembiayaan (Scale Efficiency) pada BPRS hanya bisa dilakukan dengan menerapkan dua pengukuran efisiensi yaitu model CRS dan VRS pada saat yang sama.

Dengan analisis efisiensi BPRS dengan metode DEA, dapat diketahui input dan output yang menyebabkan ketidak efisienan pada pembiayaan di BPRS. Dengan latarbelakang yang telah dikemukakan diatas, penulis tertarik unutk melakukan penelitian dengan judul "Analisis Efisiensi Pembiayaan BPRS di Jawa Timur dengan menggunakan Data Envelopment Analysis Periode 20142017."

Berdasarkan latar belakang diatas, maka rumusan masalah dari penelitian ini adalah bagaimana efisiensi pembiayaan pada BPRS di Jawa Timur tahun 2014-2017. 


\section{LANDASAN TEORI}

Menurut Sudarsono (2007:83-84) status hukum BPR diakui pertama kali dalam Pakto tanggal 27 Oktober 1988, sebagai bagian dari Paket Kebijakan Keuangan, Moneter, dan Perbankan, adapun tujuan yang dikehendaki dengan berdirinya BPRS adalah:

1. Meningkatkan kesejahteraan ekonomi umat Islam, terutama masyarakat golongan ekonomi lemah yang ada umumnya berada di daerah pedesaan.

2. Menambah lapangan kerja terutama di tingkat kecamatan, sehingga dapat mengurangi arus urbanisasi

3. Membina semangat ukhuwah Islamiyah melalui kegiatan ekonomi dalam rangka meningkatkan pendapatan per kapita menuju kualitas hidup yang memadai.

Kegiatan usaha yang dilakukan oleh BPRS selain dari menghimpun dana adalah menyalurkan dana kepada masyarakat dalam bentuk pembiayaan bagi hasil berdasarkan Akad mudharabah atau musyarakah, pembiayaan berdasarkan Akad murabahah, salam, atau istishna', Pembiayaan berdasarkan Akad Qardh Pembiayaan penyewaan barang bergerak atau tidak bergerak kepada Nasabah berdasarkan Akad ijarah atau sewa beli dalam bentuk ijarah muntahiya bittamlik dan pengambil alihan utang berdasarkan akad hawalah. BPRS juga melakukan penempatan dana pada Bank Syariah lain dalam bentuk titipan berdasarkan akad wadi' ah atau investasi berdasarkan akad mudharabah dan/atau akad lain yang tidak bertentangan dengan prinsip syariah.

Bank Pembiayaan Rakyat Syariah merupakan salah satu lembaga keuangan syariah yang beroperasi dengan prinsip bagi hasil serta mempunyai tujuan dalam meningkatkan kesejahteraan ekonomi umat Islam, terutama ekonomi lemah. Bank Pembiayaan Rakyat Syariah harus dapat menyusun kebijakan pembiayaan yang sasaran utamanya adalah mencapai tingkat keuntungan tertentu dengan optimalisasi penyaluran pembiayaan ekonomi sektoral.

Pembagian pembiayaan menurut sektor ekonomi bisa digunakan sebagai bahan evaluasi bagi bank Pembiayaan Rakyat Syariah untuk menentukan pembiayaan pada sektor ekonomi yang menjadi prioritas utama dapat memberikan kontribusi manfaat/penghasilan paling besar bagi pihak Bank Pembiayaan Rakyat Syariah. Menurut Muhammad (2004: 208) manfaat lain dari pembiayaan ekonomi sektoral bagi pihak Bank Pembiayaan Rakyat Syariah adalah adanya efisiensi pemakaian dana. Dalam rangka melakukan efisiensi dana, Bank Pembiayaan Rakyat Syariah dapat mengambil keputusan dalam menentukan arah pemberian pembiayaan dengan cara menghindari proyekproyek usaha yang sudah jenuh.

Pengertian efisiensi secara umum merupakan perbandingan antara keluaran (output) dengan masukan (input). Suatu perusahaan dapat dikatakan efisiensi yaitu apabila mampu mengelola input secara optimal untuk menghasilkan output yang maksimal. Jika perusahaan tidak mampu mengelola input secara optimal yang berarti perusahaan kekurangan atau kelebihan input, maka perusahaan dikatakan tidak efisien sebab selain orientasi pada hasil, efisiens ijuga menekankan pada nilai guna (utility).

Berdasarkan pada penelitian yang dilakukan oleh jemric dan vujcic (2002) dan juga Ascarya dan Yumanita (2006) serta konsep pengukuruan rasio efisiensi pada bank, adapun variabel-variabel yang digunakan dalam penelitian ini 
adalah: Variabel Input: (i) Hak Pihak Ketiga atas Bagi Hasil; (ii) Beban PPAP, Variabel Output: (i) Pendapatan Operasional Utama.

\section{METODE PENELITIAN}

Berdasarkan jenis data yang digunakan, maka pendekatan yang digunakan dalam penelitian ini adalah penelitian kuantitatif. Berdasarkan rumusan masalah yang telah dikemukakan, maka dapat diidentifikasikan variabel-variabel dalam penelitian ini meliputi:

a. Variabel input: Hak Pihak ketiga atas BagiHasil (I1) dan Beban PPAP (I2)

b. Variabel output: Pendapatan Operasional Utama (O1)

\section{Definisi Operasional Variabel}

Variabel Input

1. Hak Pihak ketiga atas Bagi Hasil

Hak Pihak ketiga atas Bagi Hasil merupakan Biaya yang telah dikeluarkan sebagai akibat dari penggunaan Dana Pihak Ketiga untuk penempatan dana dalam bentuk pembiayaan pada BPRS.

2. Beban PPAP

Terdiri dari beban dari Penyisihan Penghapusan Aktiva Produktif yang merupakan biaya PPAP yang telah digunakan untuk menutupi kerugian aktiva produktif (Bastian, Indra dan Suhardjono, 2006:).

\section{Variabel Output}

1. Pendapatan Operasional Utama

Pendapatan operasional utama dalam hal ini adalah pendapatan bagi hasil yaitu pendapatan yang didapat dari penempatan dana pada aktiva produktif yaitu pembiayaan.

\section{Teknik Analisis Data}

Variabel input dan output yang telah ditentukan sebelumnya dirumuskan sebagai berikut: (Moussawi dan Obeid,2011):

Dimana:

$$
\max \mathrm{h}_{\mathrm{k}}=\frac{\sum_{r=1}^{S} u_{r} y_{r j}}{\sum_{i=1}^{m} v_{i} x_{i j}}
$$

$h_{k} \quad=$ Nilai efisiensi pembiayaan

$u_{r} y_{r j} \quad=$ Ouput terbobot

$v_{i} x_{i j} \quad=$ Input terbobot

Variabel input dan output yang telah ditentukan sebelumnya akan dianalisis akan dianalisis menggunakan model Constan Return to Scale (CRS) dan model Variable Return to Scale (VRS) untuk mengetahui nilai efisiensi teknis dan efisiensi skala.

\section{HASIL DAN PEMBAHASAN}

Bank Pembiayaan Rakyat Syariah (BPRS) sebagai DMU dikatakan efisiensi secara relatif apabila nilainya sama dengan satu (nilai efisiensi $=1$ ). Sebaliknya, nilai efisiensi DMU yang kurang dari satu maka dianggap tidak efisien secara relatif. Hasil perhitungan tingkat efisiensi memiliki rentang 0 hingga 1. Perhitungan nilai efisiensi BPRS dilakukan pada 17BPRS selama periode 2014 hingga 2017.Semua informasi variabel yang digunakan untuk 
mengukur efisiensi diambil berdasarkan laporan keuangan pada website resmi Otoritas Jasa Keuangan (OJK) selama periode pengamatan tahun 2014 sampai dengan tahun 2017.

Pengukuran efisiensi Bank Pembiayaan Rakyat Syariah (BPRS) pada penelitian ini menggunakan asumsi VRS (Variable Return to Scale) dengan orientasi input. Asumsi ini digunakan karena tidak semua Bank Pembiayaan Rakyat Syariah (BPRS) (DMU) beroperasi pada skala yang optimal. Orientasi inputdigunakan karena manajemen diasumsikan memiliki kontrol yang lebih terhadap input daripada output, artinya manajemen mampu mengurangi dan menambah input dengan mudah. Berikut ini hasil efisiensi dengan asumsi VRS (Variable Return to Scale) pada orientasi input.

\section{Efisiensi Secara VRS (Variable Return Scale)}

Hasil perhitungan efisiensi menggunakan metode DEA yang berasumsikan VRS (Variable Return to Scale) orientasi input, dapat dilihat pada Gambar 1. Tingkat efisiensi teknik (VRS) pada BPRS tahun 2014-2017 cenderung mengalami fluktuasi. Gambar 1 tersebut menggambarkan rata-rata pencapaian tingkat efisiensi teknik BPRS setiap tahunnya.

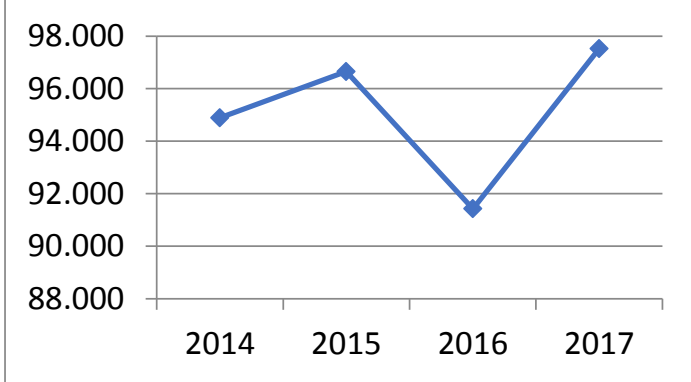

Gambar 1 Tren Efisiensi Teknik BPRS 2014-2017

Sumber: Lampiran 2, data diolah kembali

Berdasarkan Gambar 1, secara keseluruhan rata-rata nilai efisiensi teknik BPRS belum efisien, sebab nilainya masih dibawah 100\%. Gambar 1 menggambarkan efisiensi pembiayaan Bank Pembiayaan Rakyat Syariah (BPRS) pada tahun 2014 sebesar 94,9\% kemudian mengalami peningkatan beberapa persen di tahun 2015 menjadi 96,653\% lalu mengalami penurunan di tahun 2016 menjadi 91,426\% dan meningkat kembali pada tahun 2017 menjadi 97,529\%. Jadi dapat disimpulkan bahwa Bank Pembiayaan Rakyat Syariah (BPRS) dalam kurun waktu 4 tahun belum efisien dalam mengelola faktor input untuk menghasilkan output yang optimal.

Di bawah ini adalah efisiensi secara VRS yang dicapai oleh setiap BPRS periode 2014-2017:

Tabel 1 Hasil DEA Model VRS Tahun 2014-2017

\begin{tabular}{clllll}
\hline \multirow{2}{*}{ No. } & \multirow{2}{*}{ DMU } & \multicolumn{5}{c}{ VRS } \\
\cline { 3 - 6 } & & $\mathbf{2 0 1 4}$ & $\mathbf{2 0 1 5}$ & $\mathbf{2 0 1 6}$ & $\mathbf{2 0 1 7}$ \\
\hline 1 & BPRS Amanah & 0,740 & 0,943 & 1 & 1 \\
2 & BPRS Bhakti & 1 & 1 & 1 & 0,769 \\
3 & BPRS Jabal Tsur & 1 & 1 & 0,669 & 1 \\
4 & BPRS Annisa & 1 & 1 & 1 & 1 \\
5 & BPRS Jabal Nur & 1 & 1 & 1 & 1 \\
6 & BPRSUmmu & 1 & 1 & 0,798 & 1 \\
\hline
\end{tabular}




\begin{tabular}{clllll}
\hline 7 & BPRS Unawi Barokah & 1 & 1 & 0,287 & 0,835 \\
8 & BPRS Mandiri & 0,713 & 0,680 & 0,788 & 1 \\
9 & BPRS Bumi Rinjani & 1 & 0,926 & 1 & 1 \\
10 & BPRS Situbondo & 0,679 & 1 & 1 & 1 \\
11 & BPRS Rahma Syariah & 1 & 1 & 1 & 1 \\
12 & BPRS Asri Madani & 1 & 1 & 1 & 1 \\
13 & BPRS Madinah & 1 & 1 & 1 & 1 \\
14 & BPRS Bumi Rinjani Prob. & 1 & 1 & 1 & 1 \\
15 & BPRS Sarana & 1 & 0,929 & 1 & 1 \\
16 & BPRS Al-Mabrur & 1 & 0,953 & 1 & 1 \\
17 & BPRS Daya Artha & 1 & 1 & 1 & 0,976 \\
\hline
\end{tabular}

\section{Efisiensi Secara CRS (Constant Return to Scale)}

Pada perhitungan efisiensi dengan metode DEA asumsi VRS (Variable Return to Scale), hasil kedua yang diperoleh yaitu nilai efisiensi secara CRS. Efisiensi secara CRS sering disebut dengan efisiensi secara ekonomi atau efisiensisecara keselurahan (gross efficiency atau overall technical efficiency). Pada Gambar 4.3, menunjukkan bahwa tingkat efisiensi ekonomi (CRS) pada BPRS tahun 2014-2017 cenderung mengalami fluktuasi. Gambar dibawah menggambarkan rata-rata pencapaian tingkat efisiensi pembiayaan BPRS setiap tahunnya.

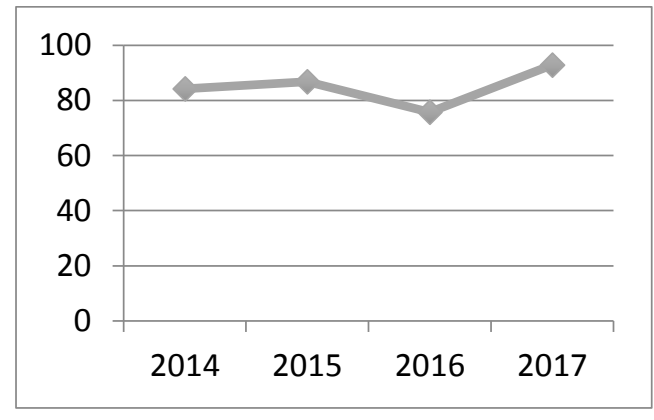

Gambar 2 Tren Efisiensi Ekonomi BPRS 2014-2017

Sumber: Lampiran 2, data diolah kembali

Berdasarkan Gambar 2, secara keseluruhan rata-rata nilai efisiensi ekonomi BPRS adalah belum efisien, karena nilainya masih dibawah $100 \%$. Gambar 2 menggambarkan efisiensi BPRS pada tahun 2014 sebesar 84,3\%, kemudian mengalami peningkatan beberapa persen di tahun 2015 menjadi 86,77\%, dan turun kembali di tahun 2016 menjadi 75,75\%. Lalu pada tahun 2017 mengalami peningkatan yang cukup besar menjadi 92,89\%. Jadi dapat disimpulkan BPRS dalam kurun waktu 4 tahun dengan asumsi CRS (semua perusahaan diasumsikan berada pada skala yang optimal) rata-rata belum efisien dalam manajerial pembiayaannya. Efisiensi secara CRS (efisiensi ekonomi) ini merupakan efisiensi kotor (gross efficiency) atau efisiensi secara keseluruhan (overall efficiency), yaitu gabungan dari efisiensi teknik (VRS) dengan mempertimbangkan efisiensi skala. Skala ekonomi tidak dapat dicapai pada semua tingkatan skala produksi, sehingga tidak semua BPRS mampu mencapai skala ekonomi yang optimal.

Di bawah ini adalah efisiensi secara CRS yang dicapai oleh setiap BPRS periode 2014-2017: 
Tabel 2 Hasil DEA Model CRS Tahun 2014-2017

\begin{tabular}{clcccc}
\hline \multirow{2}{*}{ No. DMU } & \multirow{4}{*}{ CRS } \\
\cline { 3 - 6 } & & $\mathbf{2 0 1 4}$ & $\mathbf{2 0 1 5}$ & $\mathbf{2 0 1 6}$ & $\mathbf{2 0 1 7}$ \\
\hline 1 & BPRS Amanah Sejahtera & 0,702 & 0,817 & 1 & 0,814 \\
2 & BPRS Bhakti Haji & 1 & 0,609 & 1 & 0,765 \\
3 & BPRS Jabal Tsur & 1 & 0,728 & 0,668 & 0,982 \\
4 & BPRS Annisa Mukti & 1 & 0,987 & 1 & 1 \\
5 & BPRS Jabal Nur & 1 & 0,876 & 0,985 & 0,750 \\
6 & BPRS Ummu & 0,243 & 0,617 & 0,585 & 1 \\
7 & BPRS Unawi Barokah & 1 & 1 & 0,266 & 0,570 \\
8 & BPRS Mandiri Mitra Sukses & 0,533 & 0,537 & 0,723 & 1 \\
9 & BPRS Bumi Rinjani & 0,954 & 0,907 & 1 & 1 \\
10 & BPRS Situbondo & 0,645 & 1 & 1 & 1 \\
11 & BPRS Rahma Syariah & 0,957 & 1 & 0,642 & 1 \\
12 & BPRS Asri Madani & 0,987 & 1 & 0,987 & 0,991 \\
13 & BPRS Madinah & 0,934 & 1 & 0,934 & 0,980 \\
14 & BPRS Bumi Rinjani Prob. & 1 & 0,984 & 0,989 & 1 \\
15 & BPRS Sarana & 1 & 0,861 & 1 & 1 \\
16 & BPRS Al Mabrur & 0,754 & 0,827 & 1 & 1 \\
17 & BPRS Daya Artha & 0,629 & 1 & 1 & 0,941 \\
\hline
\end{tabular}

\section{Scale Efficiency}

Berdasarkan Gambar 3, menunjukkan bahwa tingkat efisiensi skala pada Bank Pembiayaan Rakyat Syariah (BPRS) tahun 2014-2017 mengalami peningkatan. Pada tahun 2014 tingkat efisiensi skala pada BPRS sebesar 88,9\%. Pada tahun 2015 tingkat efisiensi skala pada BPRS sebesar 89,6\%. Pada tahun 2016 tingkat efisiensi skala pada BPRS sebesar 94,8\% dan terakhir pada tahun 2017 tingkat efisiensi skala pada BPRS sebesar 95,7\%. Meskipun terus mengalami peningkatan, secara keseluruhan rata-rata nilai efisiensi skala BPRS adalah belum efisien, karena nilainya masih dibawah $100 \%$.

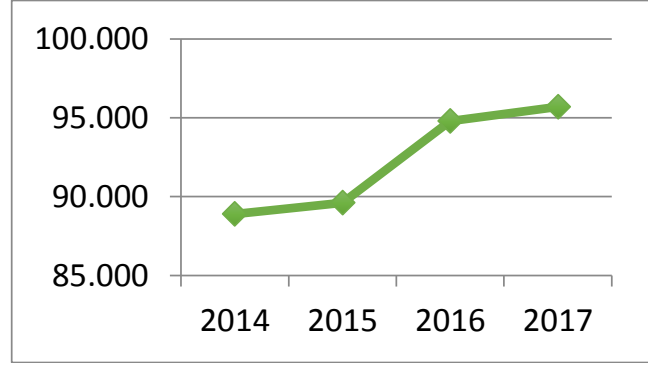

Gambar 3 Tren Efisiensi Skala BPRS 2014-2017

Sumber: Lampiran 2, data diolah kembali

Di bawah ini adalah efisiensi secara CRS yang dicapai oleh setiap BPRS periode 2014-2017 
Tabel 3 Hasil DEA Scale Efficiency Tahun 2014-2017

\begin{tabular}{|c|c|c|c|c|c|}
\hline \multirow{2}{*}{ No. } & \multirow{2}{*}{ DMU } & \multicolumn{4}{|c|}{ Skala } \\
\hline & & 2014 & 2015 & 2016 & 2017 \\
\hline 1 & BPRS Amanah Sejahtera & 0,948 & 0,866 & 1 & 0,814 \\
\hline 2 & BPRS Bhakti Haji & 1 & 0,609 & 1 & 0,765 \\
\hline 3 & BPRS Jabal Tsur & 1 & 0,728 & 0,997 & 0,982 \\
\hline 4 & BPRS Annisa Mukti & 1 & 0,987 & 1 & 1 \\
\hline 5 & BPRS Jabal Nur & 1 & 0,876 & 0,985 & 0,750 \\
\hline 6 & BPRS Ummu & 0,243 & 0,617 & 0,733 & 1 \\
\hline 7 & BPRS Unawi Barokah & 1 & 1 & 0,926 & 0,570 \\
\hline 8 & $\begin{array}{l}\text { BPRS Mandiri Mitra } \\
\text { Sukses }\end{array}$ & 0,748 & 0,790 & 0,917 & 1 \\
\hline 9 & BPRS Bumi Rinjani & 0,954 & 0,980 & 1 & 1 \\
\hline 10 & BPRS Situbondo & 0,951 & 1 & 1 & 1 \\
\hline 11 & BPRS Rahma Syariah & 0,957 & 1 & 0,643 & 1 \\
\hline 12 & BPRS Asri Madani & 0,987 & 1 & 0,987 & 0,991 \\
\hline 13 & BPRS Madinah & 0,934 & 1 & 0,934 & 0,980 \\
\hline 14 & BPRS Bumi Rinjani Prob. & 1 & 0,984 & 0,989 & 1 \\
\hline 15 & BPRS Sarana Prima & 1 & 0,927 & 1 & 1 \\
\hline 16 & BPRS Al Mabrur & 0,754 & 0,867 & 1 & 1 \\
\hline 17 & BPRS Daya Artha & 0,629 & 1 & 1 & 0,942 \\
\hline
\end{tabular}

Berdasarkan hasil penelitian dengan asumsi VRS, maka dapat disimpulkan bahwa kinerja BPRS di Jawa Timur selama tahun 2014-2017 belum efisien, baik secara ekonomi (CRS), teknis (VRS), maupun skala. Efisiensi secara skala ini mengikuti hasil dari efisiensi secara ekonomi. Jika secara ekonomi sudah dikatakan efisien, maka secara teknis akan efisien, dan otomatis secara skala juga efisien. Ketidakefisienan BPRS ini dibuktikan dengan proporsi BPRS yang tidak efisien sebesar 22,05\% secara teknis, 55,8\% secara ekonomi, dan 55,8\% secara skala (Tabel 4.7). Hal tersebut menunjukkan bahwa sebagian BPRS yang diteliti belum cukup dapat mengelola pembiayaan dengan baik. Ketidakefisienan BPRS syariah ini selain disebabkan oleh pengelolaan input dan output juga karena skala usahanya yang belum optimal.

Tabel 4 Sebaran BPRS Berdasarkan Tingkat Efisiensi Secara Ekonomi, Teknis, dan Skala

Dalam Satuan Unit

\begin{tabular}{cccc}
\hline Skor Efisiensi & CRS (Ekonomi) & VRS (Teknis) & Scale \\
\hline 1 & 30 & 53 & 30 \\
$0,0001-0,9999$ & 38 & 15 & 38 \\
Total & 68 & 68 & 68 \\
\hline
\end{tabular}

Sumber: lampiran 2, data diolah

Apabila dilihat dari Gambar 4.5, tren rata-rata nilai efisiensi mengalami fluktuasi dari tahun 2014-2017. Namun, secara keseluruhan belum mencapai efisiensi. Kemudian, pada tahun 2015 rata-rata nilai efisiensi pembiayaan BPRS di Jawa Timur dengan orientasi input, baik secara ekonomi (CRS), teknis (VRS), dan skala cenderung meningkat (Gambar 4.5). Meningkatnya tingkat efisiensi pembiayaan menunjukkan bahwa secara relatif pada 2015 
BPRS di Jawa Timur telah mampu meningkatkan efisiensi manajerial pembiayaannya. Namun, meskipun tren rata-rata nilai efisiensi baik secara CRS, VRS, maupun Skala mengalami peningkatan baik pada 2015 maupun 2017, tetapi tidak terdapat BPRS yang mengalami efisiensi terus menerus secara ekonomi (CRS) maupun skala sepanjang tahun 214-2017.

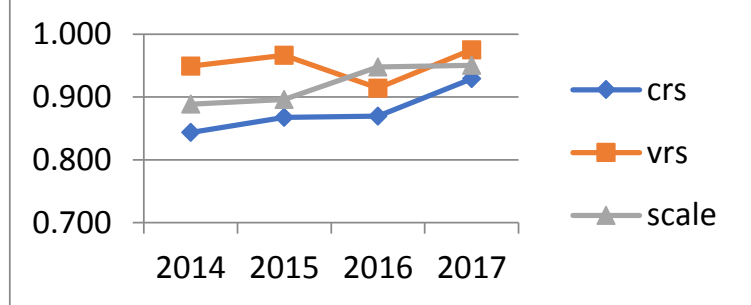

Gambar 4 Tren Rata-rata Efisiensi BPRS 2014-2017

Sumber: Lampiran 2, data diolah kembali

\section{Penetapan Target}

Perhitungan DEA tidak hanya mengukur nilai efisiensi dari masingmasing BPRS yang ada dalam sampel, tetapi juga memberikan referensi atau acuan bank bagi bank yang berada dalam kondisi inefisien menjadi efisien. Dalam penelitian ini terdapat 11 bank yang pernah mengalami ketidakefisienan selama empat tahun terakhir (2014-2017). Hasil pengujian input dan output pada BPR Syariah di wilayah Gerbangkertasusila selama empat tahun dengan menggunakan Data Envelopment Analysis (DEA) menunjukkan hasil target input dan output pada masing-masing BPR Syariah dari kondisi aktual. Angka yang dihasilkan berbeda-beda dalam bentuk persentase. Tanda negatif menunjukkan jika variabel tersebut harus diturunkan dan tanda positif menunjukkan jika variabel tersebut harus dinaikkan dari kondisi aktual untuk mencapai efisien.

Tahun 2014

\begin{tabular}{llll}
\hline \multicolumn{4}{c}{ BPRS AMANAH 2014 } \\
\hline Variabel & Actual & Target & Potential Improvement \\
\hline HPK & 4218342 & 3152875 & $-25.26 \%$ \\
PPAP & 316555 & 98427 & $-68.91 \%$ \\
POU & 26799649 & 28553303 & $6.54 \%$ \\
\hline BPRS Mandiri 2014 & & \\
\hline Variabel & Actual & Target & Potential Improvement \\
\hline HPK & 4721193 & 2516713 & $-46,69$ \\
PPAP & 1768282 & 83313,93 & $-95,29$ \\
POU & 15337340 & 15337340 & 0 \\
\hline BPRS Situbondo 2014 & & \\
\hline Variabel & Actual & Target & Potential Improvement \\
\hline HPK & 240144 & 56860,92 & $-76,32$ \\
PPAP & 95829 & 65054,71 & $-32,11$ \\
POU & 4164048 & 4164048 & 0 \\
\hline
\end{tabular}


Tahun 2015

\begin{tabular}{llll}
\hline \multicolumn{4}{l}{ BPRS AMANAH 2015 } \\
\hline Variabel & Actual & Target & Potential Improvement \\
\hline HPK & 3344625 & 3152875 & $-5,73 \%$ \\
PPAP & 6621639 & 98427 & $-98,51 \%$ \\
POU & 24737266 & 28553303 & $15,43 \%$ \\
\hline BPRS Mandiri 2015 & & \\
\hline Variabel & Actual & Target & Potential Improvement \\
\hline HPK & 4947011 & 2658742 & $-46,26$ \\
PPAP & 346432 & 88015,7 & $-74,59$ \\
POU & 16202892 & 16202892 & 0 \\
\hline
\end{tabular}

BPRS Bumi Rinjani Kepanjen 2015

\begin{tabular}{llll}
\hline Variabel & Actual & Target & Potential Improvement \\
\hline HPK & 9213193 & 8527152 & $-7,45$ \\
PPAP & 1302186 & 1205221 & $-7,45$ \\
POU & 24659336 & 24659336 & 0 \\
\hline
\end{tabular}

\section{BPRS Sarana Prima Mandiri 2015}

\begin{tabular}{llll}
\hline Variabel & Actual & Target & Potential Improvement \\
\hline HPK & 3493210 & 3245779 & $-7,08$ \\
PPAP & 535738 & 497790,6 & $-7,08$ \\
POU & 10836155 & 10836155 & 0 \\
\hline BPRS Al-Mabrur Babadan 2015 \\
\hline Variabel & Actual & Target & Potential Improvement \\
\hline HPK & 2704079 & 2577747 & $-4,67$ \\
PPAP & 942320 & 898295,8 & $-4,67$ \\
POU & 9491110 & 9491110 & 0 \\
\hline
\end{tabular}

Tahun 2016

\begin{tabular}{llll}
\hline \multicolumn{4}{l}{ BPRS Jabal Tsur 2016 } \\
Variabel & Actual & Target & Potential Improvement \\
\hline HPK & 3253087 & 2178539,61 & $-33,03$ \\
PPAP & 4086505 & 1989574,11 & $-51,31$ \\
POU & 10243473 & 10243473 & 0 \\
\hline BPRS Ummu 2016 & & \\
\hline Variabel & Actual & Target & Potential Improvement \\
\hline HPK & 408791 & 326207,5 & $-20,2$ \\
PPAP & 248059 & 197946,4 & $-20,2$ \\
POU & 3698447 & 3698447 & 0 \\
\hline BPRS Unawi Barokah 2016 & \\
\hline Variabel & Actual & Target & Potential Improvement \\
\hline HPK & 1045162 & 299919 & $-71,3$ \\
PPAP & 6413 & 1061 & $-83,46$ \\
POU & 1542533 & 1665503 & 7,97 \\
\hline BPRS Mandiri 2016 & & \\
\hline Variabel & Actual & Target & Potential Improvement \\
\hline HPK & 4272339 & 3087211 & $-27,74$ \\
PPAP & 411144 & 102199,9 & $-75,14$ \\
POU & 18814066 & 18814066 & 0 \\
\hline
\end{tabular}


Tahun 2017

\begin{tabular}{cccc}
\hline \multicolumn{6}{l}{ BPRS Bhakti Haji 2017} \\
\hline Variabel & Actual & Target & Potential Improvement \\
\hline HPK & 232786 & 178919 & $-23,14$ \\
PPAP & 233545 & 179502,4 & $-23,14$ \\
POU & 1460128 & 1466939 & 0,47 \\
\hline
\end{tabular}

BPRS Unawi barokah 2017

\begin{tabular}{cccc}
\hline Variabel & Actual & Target & Potential Improvement \\
\hline HPK & 359094 & 299919 & $-16,48$ \\
PPAP & 3059 & 1061 & $-65,32$ \\
POU & 1135668 & 1665503 & 46,65 \\
\hline
\end{tabular}

\begin{tabular}{cccc}
\hline \multicolumn{6}{l}{ BPRS Daya Artha $\mathbf{2 0 1 7}$} \\
\hline Variabel & Actual & Target & Potential Improvement \\
\hline HPK & 662849 & 647044,3 & $-2,38$ \\
PPAP & 1489371 & 1334203 & $-10,42$ \\
POU & 4189081 & 4189081 & 0 \\
\hline
\end{tabular}

\section{Pembahasan}

Secara umum, Bank Pembiayaan Rakyat Syariah (BPRS) di Jawa Timur belum efisien baik secara teknik, ekonomi, maupun skala. Rata-rata nilai efisiensi teknik sebesar 0,951, efisiensi ekonomi sebesar 0,877, serta efisiensi skala sebesar 0,915. Pada Gambar 4.5, menunjukkan tren rata-rata nilai efisiensi pembiayaan BPRS fluktuatif selama tahun 2014-2017 dan masih dibawah 100\%. Artinya, Bank Pembiayaan Rakyat Syariah (BPRS) belum mampu mengelola input secara baik untuk menghasilkan output yang optimal serta belum mampu mencapai skala usaha yang optimal. Terdapat enam BPRS yang efisien secara teknik dari 17 Bank Pembiayaan Rakyat Syariah (BPRS), namun tidak terdapat BPRS yang efisien secara ekonomi maupun skala yang dianalisis selama tahun 2014-2017 (Tabel 4.7). Ketidakefisienan Bank Pembiayaan Rakyat Syariah (BPRS) ini juga ditunjukkan dengan proporsi Bank Pembiayaan Rakyat Syariah (BPRS) yang tidak efisien pada Tabel 4.7 yaitu secara teknik (VRS) sebesar 22,05\%, secara ekonomi (CRS) sebesar 55,8\%, dan secara skala sebesar $55,8 \%$. Adanya ketidakefisienan secara teknik atau murni manajerial dan pencapaian skala usaha yang belum optimal mendorong ketidakefisienan secara keseluruhan (CRS).

Berdasarkan hasil pengukuran efisiensi dengan asumsi VRS, CRS, dan scala efficiency sebagaimana dijelaskan diatas, maka secara umum dapat disimpulkan bahwa sumber ketidakefisienan Bank Pembiayaan Rakyat Syariah (BPRS) lebih disebabkan oleh skala pembiayaannya. Hal ini ditunjukkan dengan rata-rata tingkat efisiensi secara CRS (ekonomi) dan skala lebih rendah jika dibandingkan dengan rata-rata tingkat efisiensi secara VRS (teknik) pada Gambar 4.5. Hasil ini menunjukkan bahwa ketidakefisienan pada pembiayan Bank Umum Syariah lebih dikarenakan ketidakefisienan secara skala atau ukuran operasional pembiayaan pada Bank Umum Syariah.

Pengukuran efisiensi bank cenderung terbatas pada hubungan teknik dan operasional dalam proses konversi input menjadi output (Sutawijaya dan Lestari, 2009). Oleh karena itu, yang dibutuhkan adalah kebijakan mikro yang bersifat internal, yaitu pengendalian dan alokasi input yang optimal untuk mendapatkan output yang maksimal. 
a. Ketidakefisienan yang bersumber dari input hak pihak ketiga atas bagi hasil dapat perbaiki dengan cara memperbaiki struktur pendana BPRS. Ketidakefisienan yang bersumber dari input hak pihak ketiga atas bagi hasil terjadi karena BPRS masih mengandalkan pembiayaan dari dana mahal. Artinya nilai pengembalian ke pada terhitung cukup tinggi. Dampaknya, bank syariah menjadi tak efisien karena harus menyediakan dana lebih besar untuk memberikan bagi hasil ke pada nasabah yang menyimpan uangnya di BPRS.

b. Ketidakefisienan yang berasal dari input beban ppap dapat diperbaiki dengan melakukan penilaian ketat terhadap nasabah yang ingin melakukan pembiayaan karena beban ppap merupakan beban yang muncul akibat nasabah tidak mampu mengembalikan pembiayaan yang telah diberikan. Oleh karena itu, untuk mengurangi ketidakefisienan beban PPAP dapat dilakukan dengan melakukan penilaian ketat terhadap nasabah yang ingin melakukan pembiayaan.

c. Ketidakefisienan yang berasal dari output pendapatan operasional utama dapat diperbaiki dengan upaya yang dapat dilakukan adalah pengelolaan nisbah bagi hasil yang terkait dengan input hak pihak ketiga atas bagi hasil.

\section{KESIMPULAN}

Pengukuran efisiensi dengan metode DEA asumsi VRS (Variable Return to Scale) orientasi input dan output menghasilkan tiga skor efisiensi yaitu Constant Return to Scale (CRS), Variable Return to Scale (VRS), dan Scale Efficiency (SE). Hasil ketiga efisiensi tersebut selama kurun waktu penelitian rata-rata menunjukkan tingkat efisiensi yang belum efisien. Rata-rata skor efisiensi seluruh DMU secara teknik adalah 87,7 persen, secara ekonomi sebesar 87,7 persen, dan secara skala sebesar 91,5\%. Masih terdapat 15 DMU yang tidak efisien secara teknik dan 38 DMU yang tidak efisien secara ekonomi maupun skala dari 68 DMU yang dianalisis. Hal ini berarti Bank Pembiayaan Rakyat Syariah (BPRS) belum mampu mengelola input yang dimilikis ecara optimal (VRS) serta belum mencapai skala yang optimal untuk menghasilkan output yang maksimal sehingga mendorong ketidakefisienan secara menyeluruh.

Berdasarkan perhitungan dengan metode VRS dengan menggunakan program banxia frontier analysis 3.2.2 pada 17 Bank Pembiayaan Rakyat Syariah terdapat enam BPRS yang sudah $100 \%$ mengalami efisiensi terus menerus selama periode penelitian yaitu pada tahun 2014-2017 dan 11 BPRS yang pernah mengalami inefisiensi pada periode 2014-2017. Sedangkan perhitungan dengan menggunakan metode CRS dan skala, tidak terdapat BPRS yang mengalami efisiensi terus menerus pada periode 2014-2017.

\section{Daftar Pustaka}

Bastian, I., \& Suhardjono. (2006). Akuntansi Perbankan. Jakarta: Penerbit Salemba Empat.

Cooper, W. W, et.al. (2011). Handbook on Data Envelopment Analysis. International Series in Operations Research and Management Science, Vol.124: Chapter 1 (http://www.springer. com). 
Kamaruddin, B. H, et.al. (2008). Assesing Production Efficiency of Islamic Banks and Conventional Bank Islamic Windows in Malaysia. International Journal of Business and Management Science, 1(1), 31-48.

Moussawi, C. E. L., \& Obeid, H. (2011). Evaluating the Productive Efficiency of Islamic Banking in GCC: A Non-Parametric Approach. International Management Review, 7(1), 10-21.

Maryati, S. (2014). Peran Bank Pembiayaan Rakyat Syariah dalam Pengembangan UMKM dan Agribisnis Pedesaan di Sumatera Barat, 3(1), 2-3. 